Ніна Андріянова, кандидат політичних наук Національний університет оборони України імені Івана Черняховського ORCID ID 0000-0002-7115-2445

DOI: $10.33099 / 2617-1775 / 2020-01 / 18-24$

\title{
ВІЛЬНЕ ВОЛОДІННЯ АНГЛІЙСЬКОЮ МОВОЮ ВІЙСЬКОВОСЛУЖБОВЦІВ ЗБРОЙНИХ СИЛ УКРАЇНИ ЗАПОРУКА СИЛЬНОЇ ЄВРОПЕЙСЬКОЇ АРМЇ̈
}

У статті проаналізовано сучасний стан та перспективи розвитку системи підготовки військовослужбовців з англійської мови. Визначені вимоги керівних документів до знання з іноземної мови військовослужбовців та визначені групи причин недостатнього рівня володіння іноземною мовою військовослужбовців збройних сил України.

Ключові слова: іншомовна підготовка; збройні сили; рівень володіння іноземною мовою; НАТО.

Постановка проблеми: Україна сьогодні перебуває в епіцентрі гібридної війни - нового етапу історії, що почався 3 порушення Російською Федерацією (РФ) світового порядку. Для збереження цілісності та незалежності нашій державі тепер, як ніколи, важливо мати зовнішню підтримку та гарантії безпеки, які здатні забезпечити лише міжнародні організації колективної безпеки, такі як НАТО.

Україна визначилася зі своїм вибором інтегруватися до євроатлантичних структур безпеки і з 2014 року веде активну роботу, спрямовану на реалізацію євроатлантичного курсу. Як країна-аспірант НАТО Україна має виконати низку вимог для вступу в НАТО, однією 3 ключових $\epsilon$ володіння військовослужбовцями іноземною мовою (англійською) не нижче рівня стандартизованого мовленнєвого рівня (СМР) СМР-2 (функціональний) за стандартом НАTO STANAG 6001. Але на сьогоднішній день середній показник серед військовослужбовців СМР-1 (виживання). Такий показник є недостатнім відповідно до вимог НАТО, тому в статті $є$ спроба визначити групи причин такого рівня володіння іноземною мовою військовослужбовцями Збройних Сил України та запропонували шляхи подолання даної проблеми.

Аналіз останніх досліджень і публікацій. У дослідженні проаналізовано достатньо велику кількість джерел починаючи 3 нормативно-правових документів $[1,2]$, досліджень фахівців даних питань $з$ різних структур, різних родів військ [3-8] та інтерв'ю й доповіді вищого керівного складу Збройних Сил України [8-12]. Особливої уваги заслуговує робота О. Лагодинського, який досліджував системи іншомовної підготовки у збройних силах США та Великої Британії та на основі цього досвіду надав рекомендації щодо удосконалення системи іншомовної підготовки у Збройних Силах України. Соціолінгвістичний підхід до іншомовної професійної компетентності досліджували Г. Батищева, Н. Кузнєцова, В. Петрухін. С. Жицька досліджувала особливості мовної підготовки у ВІТІ КП. Л. Гребенюк вивчала проблеми мовної підготовки 
майбутніх офіцерів ЗСУ і професійній взаємодії в міжнародних операціях 3 підтримання миру і безпеки.

Метою статті $\epsilon$ вивчити вимоги керівних документів щодо рівня володіння іноземною мовою військовослужбовців, визначити причини недостатнього рівня володіння іноземною мовою військовослужбовців збройних сил України.

Методи дослідження: системний аналіз, індукція та дедукція, порівняння, класифікація, узагальнення та систематизація.

Виклад основного матеріалу. На сьогодні зміст та рівень іншомовної компетентності військових фахівців регламентується Концепцією мовної підготовки особового складу Збройних Сил (далі - Концепція) затвердженої ще в 2009 році, яка визначає принципи мовної підготовки особового складу, головні завдання щодо їі вдосконалення, етапи та шляхи реалізації поставлених завдань. Зокрема в Концепції визначено, що мовна підготовка особового складу Збройних Сил - це складова частина загальної системи підготовки військовослужбовців та працівників Збройних Сил, яка являє собою комплекс узгоджених між собою, планомірних і послідовних заходів навчального та тренувального характеру, спрямованих на вивчення особовим складом іноземних мов у обсязі, визначеному як необхідний для виконання посадових обов'язків, служби (роботи) та навчання за кордоном [1, с. 2].

У Концепції подані описи рівнів володіння іноземною мовою. Згідно 3 нею рівень володіння іноземною мовою - це сукупність мовних знань, мовленнєвих навичок та вмінь, що визначає здатність особи до їі практичного використання. У Збройних Силах цей рівень оцінюється за шкалою стандартизованих мовленнєвих рівнів (далі - СМР), які відповідають рівням мовленнєвої компетенції за мовним стандартом HATO “STANAG 6001". Метою даного стандарту $є$ надання опису рівнів володіння мовою за чотирма основними видами мовленнєвої діяльності.

В описі надаються чіткі роз'яснення рівнів мовної компетентності згідно 3 загальноприйнятими видами мовленнєвої діяльності: аудіювання, говоріння, читання, письмо.

В документі визначено шість рівнів мовленнєвої компетентності від 0 до 5:

Рівень 0 - Відсутність практичного вміння

Рівень 1 - Виживання

Рівень 2 - Функціональний

Рівень 3 - Професійний

Рівень 4 - Експертний

Рівень 5 - Досконалий/рівень досвідченого носія мови [5, с.27].

За вимогами НАТО необхідною умовою вступу до альянсу $\epsilon$ знання іноземної мови (англійської) офіцерами не нижче рівня СМР-2. Про це в своїх доповідях наголошують представників керівного складу Збройних Сил [9-12]. Наприклад, генерал-лейтенант Сергій Корнійчук у своєму інтерв'ю підкреслив, що: “вивчення англійської мови буде мотивацією для тих, хто розраховує на просування по службі. Вивчення англійської мови - один із шляхів наближення до стандартів НАТО" [9]. 
Генерал-лейтенант Сергій Наєв наголошував, що важливо володіти військовослужбовцями англійською мовою для того щоб “вивчати документи в оригіналі. Ментально бути такими, як наші західні партнери” [10].

Неодноразово в своїх доповідях наголошував начальник Генерального штабу генерал-лейтенант Руслан Хомчак, що знання іноземної мови є слабким місцем в розвитку ЗСУ: “на жаль, на цей час ми поки що не досягли здатності більшості керівного складу Збройних Сил України вільно спілкуватись англійською мовою з іноземними колегами. Це - одне 3 проблемних місць та, водночас, наших важливих завдань на майбутнє. Зазначене стосується впровадження стандартів НАТО та нарощування спроможностей української армії діяти спільно 3 військовими формуваннями інших держав під час проведення операцій з підтримання миру та безпеки, а також заходів підготовки військ (сил), у першу чергу - багатонаціональних навчань" [11].

I дійсно, на сьогоднішній день низький рівень володіння військовослужбовців іноземною мовою $\epsilon$ проблемою, англійська мова $\epsilon$ робочою мовою в НАТО, а іï незнання військовослужбовцями забезпечує дистанцію для співпраці з альянсом.

На основі проаналізованої літератури визначені причини низького рівня володіння іноземною мовою військовослужбовцями ЗСУ та проблемні сторони іншомовної підготовки в Збройних Силах України. Так можна виокремити чотири групи:

1. Вдосконалення рівня володіння іноземною мовою стоїть не на першому місті в списку професійного зростання для самого військовослужбовця і для Збройних Сил в цілому. Ми не можемо нехтувати той факт, що при наявному збройному конфлікті та окупованих територіях пріоритетними задачами для військовослужбовців $є$ підвищення бойових та оперативних спроможностей, а підвищення рівня володіння іноземною мовою в рамках підвищення професіонального рівня все одно буде на другому плані.

2. Недостатній рівень підготовки з іноземної мови у ВВНЗ. Проблема викликана в першу чергу різним рівнем абітурієнтів перед вступом у ВВНЗ, складністю застосування індивідуального підходу до вивчення мов, застарілими методиками викладання іноземної мови та ін. Тому на випускних іспитах курсанти демонструють знання іноземної мови в середньому CMP-1.

Складно не погодитись з рекомендаціями професора О. Лагодинського [2], який взагалі пропонує прибрати дисципліну “іноземна мова" 3 переліку дисциплін у вищих військових навчальних закладах і перевести іiі у систему курсової підготовки. Що, на нашу думку дасть більш продуктивні результати, тому що курсанти будуть відібрані за рівнем знань, відповідно до кожного рівня буде застосовані різні програми з вивчення, буде більше годин мовної практики.

3. Стажування закордоном досі $\epsilon$ недоступним широкому колу військовослужбовців ЗСУ, особливо курсантам (студентам) ВВНЗ. Практика спілкування з носіями мови змогла б допомогти подолати психологічні бар'єри, які інколи перешкоджають іншомовній мовленнєвій діяльності та така практика 
заклала би гарну основу для подальшого індивідуального вдосконалення рівня англійської мови самим військовослужбовцем.

4. Освітні установи Міністерства оборони України здатні забезпечити відповідну курсову підготовку приблизно для 1,5 тисяч військовослужбовців на рік, тоді як цього потребують десятки тисяч офіцерів [5]. Також слід згадати, що відповідно до Інструкції про курси іноземних мов у Збройних Силах України [2] наявні конкретні критерії відбору кандидатів, тобто не всі бажаючи можуть таким критеріям відповідати. Також в Інструкції зазначено, що "на курси іноземних мов не можуть бути направлені особи, які упродовж останніх 3 років навчалися на курсах загальної або спеціальної мовної підготовки", але фактично основна більшість військовослужбовців за свою військову службу закінчує лише раз такі курси. Тобто після їх закінчення підтримання та підвищення рівня знань іноземної мови залежить лише від військовослужбовця.

Висновки. Проведене дослідження дозволяє зробити висновок, що сьогодні наявна проблема недостатнього рівня володіння військовослужбовців іноземною мовою (англійською) відповідно до вимог НАТО і в досліджені виокремлені чотири групи причин цього низького рівня та деякі рекомендації 3 подолання наявної проблеми. В той же час дослідження змушує нас констатувати, що вирішення порушеної теми залежить i від самого військовослужбовця в тому числі, якого в свою чергу необхідно підтримувати та мотивувати.

Необхідно зауважити, так як досягнення необхідного рівня володіння військовослужбовцями Збройних Сил України іноземною мовою $є$ одним 3 пріоритетних та одночасно проблемних завдань для Збройних Сил, то необхідно i в подальшому досліджувати дане питання в пошуках найоптимальніших шляхів вирішення даної проблеми.

\section{ЛІТЕРАТУРА}

1. Про затвердження Концепції мовної підготовки особового складу Збройних Сил України та плану реалізації Концепції мовної підготовки особового складу ЗСУ: Наказ Міністра оборони України від 01 червня 2009 р. № 267. Київ : МО України, 2009. 34 с.

2. Про затвердження Інструкції про курси іноземних мов у Збройних Силах України : Наказ Міністерства оборони України від 23.05.2017 № 286. URL: https://zakon.rada.gov.ua/laws/show/z0746-17

3. Батищева Г., Кузнєцова Н., Петрухін В. Іншомовна професійна компетентність у курсантів військового закладу вищої освіти: соціолінгвістичний підхід. Мова i cycniльство. 2019. Випуск 10. С. 156-163

4. Семененко Л.М. Федорович М.А Кондратенко О.І. Целіщев І.О. Основні методичні особливості еволюції викладання іноземних мову вищих військових навчальних закладах ( аналіз та оцінка їх ефективності в період 1950-2017p.p .) Збірник наукових пращь Військової академії(м. Одеса). № 2 (8) 2017. С.178-186.

5. Величко О. О. Управлінські вимоги до змісту іншомовної компетентності військових фахівців у процесі їх підготовки. Військова освіта. 2016. № 2. С. 25-32.

6. Лагодинський О. Іншомовна підготовка у збройних силах Сполучених Штатів Америки та Великої Британії: досвід для України. Збірник наукових працуь Наџіональної академії Державної прикордонної служби України. Серія: педагогічні науки. 2019. Вип. 3. С. 164-179.

7. Жицька С.А. Мовна підготовка у ВITI КП: 2007. URL: https://kpi.ua/721-6 
8. Гребенюк Л. Практична розробка структурної моделі формування готовності майбутніх офіцерів ЗСУ до професійної взаємодії в міжнародних операціях з підтримання миру і безпеки. Педагогічні науки: теорія, історія, інноваційні технологї : науковий журнал. 2019. № 4 (88). С. 27-38.

9. Ј-структура дозволить говорити однією мовою з органами управління країн-членів HATO, - Сергій Корнійчук. URL: https://www.armyfm.com.ua/j-struktura-dozvolit-govoritiodniyeyu-movoyu-z-organami-upravlinnya-krain-chleniv-nato---sergij-kor/

10. 32020 року на нові організаційні структури, які діють у НАТО, переходять органи військового управління 3С України - генерал-лейтенант C.Haєв. URL: http://www.mil.gov.ua/news/2019/12/21/z-2020-roku-na-novi-organizaczijni-strukturi-yaki-diyutu-nato-perehodyat-organi-vijskovogo-upravlinnya-zs-ukraini-general-lejtenant-s-naev/

11. Одне з проблемних місць Збройних сил України - володіння англійською мовою. URL: https://www.depo.ua/ukr/war/khomchak-nazvav-slabke-mistse-zsu-201910091042384

12. Кабаненко I. Україна - HATO: про необхідне та достатнє. Главком. 2018. URL: https://glavcom.ua/columns/kabanenko/ukrajina-nato-pro-neobhidne-ta-dostatnje-486410.html

\section{REFERENCES}

1. Pro zatverdzhennia Kontseptsii movnoi pidhotovky osobovoho skladu Zbroinykh Syl Ukrainy ta planu realizatsii Kontseptsii movnoi pidhotovky osobovoho skladu ZSU [On approval of the Concept of language training of personnel of the Armed Forces of Ukraine and the plan of implementation of the Concept of language training of personnel of the Armed Forces of Ukraine]: Nakaz Ministra oborony Ukrainy vid 01 chervnia 2009 r. № 267. Kyiv : MO Ukrainy, 2009. 34 s.

2. Pro zatverdzhennia Instruktsii pro kursy inozemnykh mov u Zbroinykh Sylakh Ukrainy [On approval of the Instruction on foreign language courses in the Armed Forces of Ukraine] : Nakaz Ministerstva oborony Ukrainy vid 23.05.2017 № 286. URL: https://zakon.rada.gov.ua/laws/show/z0746-17

3. Batyshcheva H., Kuznietsova N., Petrukhin V. Inshomovna profesiina kompetentnist u kursantiv viiskovoho zakladu vyshchoi osvity: sotsiolinhvistychnyi pidkhid [Foreign-language professional competence in cadets of a military institution of higher education: a sociolinguistic approach]. Mova i suspilstvo. 2019. Vypusk 10. S. 156-163

4. Semenenko L.M. Fedorovych M.A Kondratenko O.I. Tselishchev I.O. Osnovni metodychni osoblyvosti evoliutsii vykladannia inozemnykh movu vyshchykh viiskovykh navchalnykh zakladakh ( analiz ta otsinka yikh efektyvnosti v period 1950-2017r.r .) [The main methodological features of the evolution of foreign language teaching at higher military educational institutions (analysis and evaluation of their effectiveness in the period 1950-2017)]. Zbirnyk naukovykh prats Viiskovoi akademii(m. Odesa). № 2 (8) 2017. C.178-186.

5. Velychko O. O. Upravlinski vymohy do zmistu inshomovnoi kompetentnosti viiskovykh fakhivtsiv $u$ protsesi yikh pidhotovky [Management requirements for the content of foreign language competence of military professionals in the process of their preparation]. Viiskova osvita. 2016. № 2. S. 25-32.

6. Lahodynskyi O. Inshomovna pidhotovka u zbroinykh sylakh Spoluchenykh Shtativ Ameryky ta Velykoi Brytanii: dosvid dlia Ukrainy[Foreign language training in the United States and United Kingdom Armed Forces: Experience for Ukraine]. Zbirnyk naukovykh prats Natsionalnoi akademii Derzhavnoi prykordonnoi sluzhby Ukrainy. Seriia: pedahohichni nauky. 2019. Vyp. 3. S. 164-179.

7. Zhytska S.A. Movna pidhotovka u VITI KP[Language training in VITI KP]: 2007. URL: https://kpi.ua/721-6

8. Hrebeniuk L. Praktychna rozrobka strukturnoi modeli formuvannia hotovnosti maibutnikh ofitseriv ZSU do profesiinoi vzaiemodii $\mathrm{v}$ mizhnarodnykh operatsiiakh z pidtrymannia myru i bezpeky [Practical development of a structural model for the formation of future readiness of the Armed Forces officers for professional cooperation in international peacekeeping and security operations]. Pedahohichni nauky: teoriia, istoriia, innovatsiini tekhnolohii : naukovyi zhurnal. 2019. 
№ 4 (88). S. 27-38.

9. J-struktura dozvolyt hovoryty odniieiu movoiu z orhanamy upravlinnia krain-chleniv NATO, [J-structure will allow to speak the same language with the governing bodies of NATO member states] - Serhii Korniichuk. URL: https:/www.armyfm.com.ua/j-struktura-dozvolitgovoriti-odniyeyu-movoyu-z-organami-upravlinnya-krain-chleniv-nato---sergij-kor/

10. Z 2020 roku na novi orhanizatsiini struktury, yaki diiut u NATO, perekhodiat orhany viiskovoho upravlinnia ZS Ukrainy [Since 2020, new governing bodies operating in NATO have been transferred to the military command of the Armed Forces of Ukraine] - heneral-leitenant S.Naiev. URL: http://www.mil.gov.ua/news/2019/12/21/z-2020-roku-na-novi-organizaczijnistrukturi-yaki-diyut-u-nato-perehodyat-organi-vijskovogo-upravlinnya-zs-ukraini-general-lejtenants-naev/

11. Odne z problemnykh mists Zbroinykh syl Ukrainy - volodinnia anhliiskoiu movoiu[One of the problematic places in the Armed Forces of Ukraine is English]. URL: https://www.depo.ua/ukr/war/khomchak-nazvav-slabke-mistse-zsu-201910091042384

12. Kabanenko I. Ukraina - NATO: pro neobkhidne ta dostatnie [Ukraine - NATO: about the necessary and the sufficient]. Hlavkom. 2018. URL: https://glavcom.ua/columns/kabanenko/ ukrajina-nato-pro-neobhidne-ta-dostatnje-486410.html

\section{РЕЗЮМЕ}

Нина Андриянова, кандидат политических наук Национальный университет обороны Украины имени Ивана Черняховского

\section{Свободное владение английским языком военнослужащих вооруженных сил Украины залог сильной Европейской армии}

B статье проанализировано современное состояние и перспективы развития системы подготовки военнослужащих по английскому языку. Определены требования руководящих документов в знания иностранного языка военнослужащии и определенные группы причин недостаточного уровня владения иностранным языком военнослужащих вооруженных сил Украины.

Ключевые слова: языковая подготовка; вооруженные силь; уровень владения иностранным языком; НАТО.

\section{SUMMARY}

Nina Andriianova,

$\mathrm{PhD}$ (Political sciences)

National Defence University of Ukraine named after Ivan Chernyahovskyi

\section{Fluency in English by Ukrainian military is a guaranty of strong European Army}

Introduction. Ukraine has chosen to integration in Euro-Atlantic security structures, and since 2014 has been actively pursuing a Euro-Atlantic course. As a NATO graduate country, Ukraine has to fulfill a number of requirements for NATO membership, one of the key ones being proficiency in military personnel in a foreign language (English) not lower than the SMR-2 (functional) according to the NATO STANAG 6001 standard.

However, the average among militaries is SMR-1 (survival). Such an indicator is insufficient to meet NATO requirements, so the article attempts to identify groups of reasons for such a level of foreign language proficiency by military personnel of the Armed Forces of Ukraine and suggested ways of overcoming this problem. 
Purpose. To study the requirements of the governing documents on the level of foreign language proficiency of military personnel, to determine the reasons for the lack of proficiency in the foreign language of military personnel of the Ukrainian Armed Forces.

Research methods: system analysis, induction and deduction, comparison, classification, generalization and systematization.

Results: identifying groups of reasons for a low level in a foreign language and some recommendations for improving it.

Originality. At present, the level in a foreign language (English) by military personnel of the Armed Forces of Ukraine is a rather problematic issue. Unless military personnel in the Armed Forces of Ukraine increase, their level of foreign language skills to NATO requires there can be no question of joining NATO. Therefore, the study identified the reasons for the low level in a foreign language proficiency by military personnel of the Armed Forces of Ukraine and some recommendations for improving it that may be useful for solving this problem.

Conclusion. The study suggests that there is currently a problem of a low level in in a foreign language (English) and identifies four groups of reasons for this low level and some recommendations to address the current problem. At the same time, the research leads us to state that the solution of the topic raised depends on the militaries (himself), including, who, however, needs to be supported and motivated.

It should be noted that the achievement of the required level in a foreign language by Ukrainian Armed Forces personnel is one of the priority and at the same time problematic tasks for the Armed Forces, so it is necessary to further investigate this issue in search of the best ways to solve this problem.

Key words: foreign language training; armed forces; level in a foreign language; NATO. 